\title{
How to Reflect Spirit of the Time in the Current Architecture of Iran
}

\author{
Maedeh Arabi \\ Architecture Group, University of Semnan, Semnan, Iran
}

Email address:

Ma_arabi@yahoo.com

To cite this article:

Maedeh Arabi. How to Reflect Spirit of the Time in the Current Architecture of Iran. International Journal of Science, Technology and Society. Special Issue: Research and Practice in Architecture and Urban Studies in Developing Countries. Vol. 3, No. 2-1, 2015, pp. 64-69. doi: $10.11648 /$ j.ijsts.s.2015030201.23

\begin{abstract}
With over a thousand of years of historical heritage, Iran has always been among the greatest civilizations in the history. The early pre-Islamic architecture of Iran has represented the identity of Iranian people through the times. Furthermore, after the emergence and spread of Islam in Iran, the Iranian architecture has continued to maintain its well-established historical values. However, since the reign of Qajaryan dynasty in Iran, which was coincided with the Renaissance period in Europe, Iranian architecture has gradually been declined and has lost its links with its glorious days. Advances in modern technology and sciences and rapid changes in the world conditions have also caused a further separation of the Iranian nation from their past glorious roots. As a result, the modern architecture in Iran hardly includes and reflects signs of its past civilization. The present study aims to provide a solution to the problem so that the cultural and historical roots of Iranian architecture can be maintained and reflected in modern structures. In this study, a concept to case methodology has been proposed using discursive practices. For this purpose, the concept of «identity» has first been identified, and then the way to combine the Iranian and Islamic architectural atmospheres has been discussed. After that, some examples for the implementation of combined Iranian - Islamic architecture in Iran have been provided. Finally, some enduring principles of the Iranian architecture for the design of the current Iranian architecture have been extracted. These principles are the persistent values which have existed in architecture of Iran. Thus, based on the results of this paper, Taking inspiration from authentic and sustainable patterns of Iranian architecture and modern expression of them using creativity and skill, is the best way for reflecting the identity in contemporary architecture of this land.
\end{abstract}

Keywords: Contemporary Architecture, Identity, Iranian, Islamic

\section{Introduction}

The World today, trying to keep identity, is one of the main quarrels of nations and architecture of Iran is not an exception in this. Iranian Islamic identity reflects cultural specifications of this land. This is the Issue that should be manifested in all facets of life, especially in the field of architecture. Achieving identity in architecture is very important in contemporary architecture. Today requiring the cities with Islamic Iranian identity has become a public and pervasive demand. So that in addition to the legal institutions and formal structures of society, many of the people are also applying it. There are many questions in this area that this paper is a step toward answering them; such as what is the meaning of identity? How has the sense of identity been changed over the time? What qualities have formed the Architectural identity throughout history?

\section{The Concept of Identity}

Identity is a factor of recognition of individuals, objects and groups. So the word «identity» requires an understanding of two opposite meaning: similarity and difference. These two meanings are in contrast with binary opposition. But in fact they are complementary of one concept, name of identity: intergroup similarity despite out-group differences. In the concept of identity, necessarily, There is an own and another (a self and a non-self). Each object has specific and unique characteristics that make it distinguishable from other objects. These definitions show two conflicting aspects of identity which can be expressed with "insider similarity and differentiation of others". 


\section{Identity from the Perspective of Architects and Urban Planners}

"The concept of identity, in terms of architecture and urbanism, has often two complementary parts; first, creating memories in persons and second, distinctiveness of the individuals. So the identification is a process which compares object with its data in mind." [1] "Walter Bauer believes that the Identity is the large and small differences which make recognition of a place and environmental legibility. Marius Calin emphasizes the importance of the differences between environments. He defines «identity» as an attention to the character of environment, Avoiding monotony and Similarity of urban environments through displaying Special features of it. In Rapaport opinion, «identity» is a detection of one from another"[2]. Christopher Alexander thinks «identity» is physical embodiment of anonymous qualities in buildings which are the main basis for the life and soul of human, city, building or wilderness but we cannot put a name to them.

\section{Appearance of Identity in Body}

The method adopted in this paper is a physical method, based on observations. The physical identity, in general means physical differences in architecture. In fact, the physical identity is a set of features which distinguish the building appearance from others and reveals its resemblance to the same. The building, at the same time of preserving its identity should accept the evolution and finally lead to the creation of a totality.

\subsection{Differentiation/Similarity}

In general, identity comes when man faces with the «other». In other words, Identity will appear when the person compares himself with someone else. In contemporary urban and architecture, «identity» has a special place. Concepts such as readability, meaning and sense of place directly relate to distinction of a place and emphasize on maintaining it.

\subsection{Continuity/ Evolution}

Looking at the nature shows that everything is changing and renewing all the time without losing its essence. In this concept, it is important for each place to preserve its identity during the transformation. Continuity and evolution is also implies that despite all the changes, something stays with no change.

\section{Identity Reflection in Architecture}

Humans since the beginning of creation have concerned about the identity and always shown their dependence to their roots in their art. Consequently, human identity also in architecture is manifest. The relationship between architecture and the land, in which it arises, is the same which human has with his culture and Customs. Perhaps we can interpret the architecture with identity as an «identifiable architecture»; an architecture that can recognize, because there is a background of it and it has clear family and lineage. "The own architecture is also a kind of architecture that is familiar. The familiar is identifiable and everybody can understand it. To be familiar occurs when there is a history of cognition. The own architecture is an independent architecture, and not from the outside in; rooted in its own culture and comes from the behaviors, beliefs, cultural traits and customs of the people." [3]

Most thinkers has valued and historical insights to «identity»."They take aboriginal identity priority over the global identity and are believed to the «own architecture». They believe that creating our own architecture, with the current mechanism can characterize us in the field of architecture in the world." [4] In fact, the main purpose of the architectural identity is the meaning that refers to the cultural spirit of its formation context.

\section{The Identity of Iranian Architecture (Being Iranian)}

In reference [5] Dr. Hojjat believes that the specific identity of Iranian architecture is the result of the differences between this cultural manifestation and its matches in other cultures and the way to understand this quality of Iranian architecture is in rereading the various dimensions of Iranian culture again. "Being Iranian is composed of two elements, the territory and the history; time and place. We have been living in this land and we have taken some features of it. The one who lives in a country like Iran geographically; the Land in the path of all the East and West gets features that are different from someone who lives in a corner of the world. So, one of the issue is that we have lived in this land with this geography, and the other is that we have passed on thousands of years. In fact, the time we have passed on and the events that have happened to us create our today; and this is «being Iranian»." [5] In fact, the Iranian identity is the memories of events occurred during the time (history) in place of Iran (geography); which all Iranians are participants in shaping them.

\section{The Effect of Islam on the Identity of Iranian Architecture}

Iranian architecture has been existed many years before the advent of Islam in Iran. Iranian identity much earlier formed and its reflection was visible in the architecture of Iran. The advent of Islam in Iran caused a new definition of Iranian identity; a definition that did not contravene the previous identity, but guided it towards certain route to make a full-fledged Iranian identity named as Iranian-Islamic identity. In reference [5] Dr. Hojjat implies the effect of the appearance of Islam on «being Iranian» in such expression: 
"I think the «belief» and «religion» are not part of the culture. The culture is begotten of time and place; namely, all those features that humans take from his time and place. Now, along with the culture, there is a belief; something out of the history and geography, and invites the culture to a sequential order. It accepts or does not accept. When culture accepts the belief, the belief tries to sort the factors which are result of history and geography. In fact, it compares the human features that are set in this location and history with its values for a perfect man. Religion, in fact, is like a magnet that you put under the page which you have poured different Filings on it. The magnet does not change some of the filings, rotate some of them in place and move some very much and displace them. So religion tries to take human into an ideal man which is intended. Religion will determine the shape of human life, of course, with its cultural context." [5]

\section{Iranian-Islamic Architecture}

In the land of Iran, exiting from «being Iranian» is not possible, because the people of this land are Iranians; exiting from « Islamism» is also impossible, because the people are living with this belief and they want to have it. Therefore, the Islamic Iranian life with all its details must be current to preserve the identity of people." The part «Iranian» in Islamic Iranian architecture, which is result of the territory and history, is very important and denying it will cause huge losses. Now, «Islamic» means if we want to match these specifications with the ideals that Islam tells us, which we approve and which we deny. During the period that we have been living in the Islamic era, we could match some Iranian's specifications with Islamic ideals and we could not do so for some others. Therefore, to understand the situation we have been in, not only the recognition of the temporal- locational context namely «being Iranian» is necessary, but also The meaning of «Islam» that actually leads the «being Iranian» into its main purpose, Should be investigated. Naturally, the architecture in Iran must have both of these." [5] So Iranian-Islamic architecture is a product of the interaction of three forces of history, geography and belief.

\section{The Changes of Iranian Architecture from Past to Present}

The Iranian traditional architecture was a path that changes happened slowly in it; however it kept its principles fixed. The main goal of these principles was providing the best lifestyle for humans; the style that supply the both physical and mental comfort for human. These fixed principles were the cause that remains the traditional Iranian architecture throughout history. But contemporary architecture now is out of the former path of Iranian architecture. Sudden changes take place with no backing or special purpose. In most of the buildings, human needs have been immolated on Fermi games of architects. The fundamental and basic concepts of architecture have lost their meaning." Today we say that the architecture should be stable; the entire thing we can understand of sustainability is being stable against some simple natural powers such as earthquake, wind, rain and fire, while these are the most oppressed forces that affect the buildings; the biggest destructors are humans and their ideals. So when you want a sustainable architecture, it should be matched with all the demands of humans during a long time. When the architect is able to achieve the kind of architecture that is adapted to the fundamental demands of human, the architecture is stable, so it always stays." [5]. such works are beyond time and place, and this makes them valuable and stable throughout history.

\section{The Importance of Understanding the Traditional Architecture of Iran and Its Impact on the Identity of Contemporary Architecture}

Human has to comply with his own past and also is free to change it. The achievements and experiences of the past architects of Iran, trying to retain their own religious beliefs while also being an Iranian, and appearing these two features in their works, can be a good way for architects today. Zeyneddin believes that architectural principles and concepts of the past are source of inspiration and provide solutions for the prospective Imagination. In reference [4] Shayan quoted from Zeyneddin that "the phenomenon of light, discipline and peace, the unity of geometry, internal and external space, the both simplicity and complexity, all offers brilliant solutions, tangible to us." Dr. Hojjat believes that their experiences are extremely useful and essential to find solutions to the problems of contemporary architecture. "At that time an issue was proposed and they would fix it and now we can strengthen problem-solving power by reviewing it. But we do not want to solve the same problem; our problem is related to today. We, architects; in fact can study the process of reaching from question to answer in this land, with Islamic belief, by noticing the architecture of the past." [5]

\section{The Reflection of Iranian Identity (Tradition) in Contemporary Architecture}

Linking with the past architecture is not meant to use the same technology, materials, faces or historical forms; but it is a concept and spirit sublimity of the traditional architecture which regardless of the material conditions of its time and place, can be manifested in the forms and new technology. "There is no stabilized form to show the concepts of culture. For advancement and promotion of the art and architecture of a country, clever innovation should be utilized to achieve these sublime goals." [6] Based on some of the works of contemporary architecture, Soltanzadeh classifies reflection of tradition as follows: 
Table 1. The reflections of Iranian identity in contemporary architecture.

\begin{tabular}{|c|c|c|c|c|c|}
\hline \multicolumn{6}{|c|}{$\begin{array}{l}\text { Reflection of tradition in } \\
\text { contemporary architecture }\end{array}$} \\
\hline Explicit reflection (Direct) & \multirow{2}{*}{\multicolumn{3}{|c|}{$\begin{array}{l}\text { Applying some compositions, elements or traditional decorating, } \\
\text { directly } \\
\text { Applying compositions, elements or other characteristics of Iranian } \\
\text { architecture with a personal interpretation }\end{array}$}} & \multirow{2}{*}{\multicolumn{2}{|c|}{$\begin{array}{l}\text { Identifiable for architects and unskilled } \\
\text { people } \\
\text { Identifiable for architects and familiar for } \\
\text { unskilled people }\end{array}$}} \\
\hline Non-explicit reflection & & & & & \\
\hline \multicolumn{6}{|c|}{ 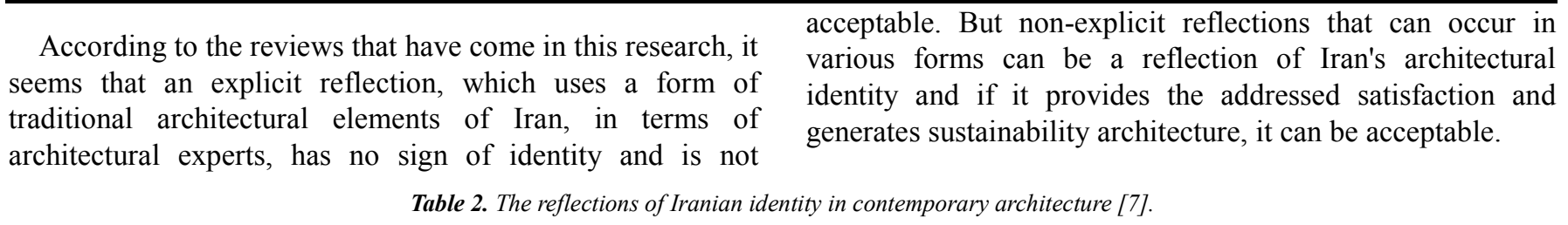 } \\
\hline \multicolumn{2}{|c|}{$\begin{array}{l}\text { Reflection of tradition in contemporary } \\
\text { architecture }\end{array}$} & \multicolumn{3}{|l|}{ Features } & Instance \\
\hline \multirow{2}{*}{ Explicit reflection (Direct) } & \multirow[t]{2}{*}{ Comprehensive } & \multirow{2}{*}{\multicolumn{3}{|c|}{$\begin{array}{ll}\begin{array}{l}\text { Direct use of some elements or } \\
\text { combination and especially using } \\
\text { the traditional decorating }\end{array} & \begin{array}{l}\text { Similarity to the traditional } \\
\text { buildings while using modern } \\
\text { materials }\end{array} \\
\begin{array}{l}\text { Using only traditional decorative } \\
\text { elements such as tiles, and so in a } \\
\text { traditional manner }\end{array} & \begin{array}{l}\text { Overall composition and plan } \\
\text { based on the basic framework of } \\
\text { contemporary design }\end{array}\end{array}$}} & Sharif University mosque \\
\hline & & & & & $\begin{array}{l}\text { The faculty of theology of } \\
\text { Tehran }\end{array}$ \\
\hline \multirow{4}{*}{ non-explicit reflection } & Comprehensive & $\begin{array}{l}\text { Using the traditional materials, } \\
\text { elements and combination with a } \\
\text { new interpretation and regulatory }\end{array}$ & \multicolumn{2}{|c|}{$\begin{array}{l}\text { Designing with processing new } \\
\text { and creative ideas }\end{array}$} & $\begin{array}{l}\text { The building of the cultural } \\
\text { heritage }\end{array}$ \\
\hline & Processing idea & \multicolumn{3}{|c|}{ Getting idea of the traditional architecture obviously } & Tomb of Baba Taher \\
\hline & $\begin{array}{l}\text { Case and } \\
\text { metaphorical }\end{array}$ & $\begin{array}{l}\text { Using of some traditional } \\
\text { architectural signs as metaphorical } \\
\text { and personal interpretation }\end{array}$ & \multicolumn{2}{|c|}{$\begin{array}{l}\text { The lack of readability and } \\
\text { being impossible to identify } \\
\text { from the views of ordinary } \\
\text { people }\end{array}$} & City Theater \\
\hline & $\begin{array}{l}\text { Comprehensive } \\
\text { and ecological }\end{array}$ & \multicolumn{3}{|c|}{$\begin{array}{l}\text { Using of some frameworks, features and elements of Iranian architecture } \\
\text { innovative and comprehensively. }\end{array}$} & New Shushtar \\
\hline
\end{tabular}

\section{The Features and Principles of Iranian Architecture with Identity}

Various architects and experts, in the field of identity and features of Iranian-Islamic architecture, enumerate several principles. The study of their theories shows many commons in the form of several names of these principles. By studying these features and finding commonalities, the attributes of Iranian Islamic architecture can be classified in three groups: Fermi characteristics, templates and conceptual attributes.

Table 3. The attributes of Iranian Islamic architecture.

\begin{tabular}{lll}
\hline $\begin{array}{l}\text { The attributes of } \\
\text { Iranian Islamic } \\
\text { architecture }\end{array}$ & features & Sample case \\
\hline Fermi characteristics & $\begin{array}{l}\text { Shape features of Iranian } \\
\text { building } \\
\text { (Structural or Decorative) }\end{array}$ & $\begin{array}{l}\text { Types of arches and } \\
\text { domes }\end{array}$ \\
Templates & $\begin{array}{l}\text { Abstract deriving from an } \\
\text { architectural fact }\end{array}$ & $\begin{array}{l}\text { Different use of } \\
\text { foursome patterns, } \\
\text { cruciform pattern } \\
\text { and etc. }\end{array}$ \\
& $\begin{array}{l}\text { Continuity and repetition } \\
\text { of concepts, independent } \\
\text { of the particular form or } \\
\text { pattern }\end{array}$ & $\begin{array}{l}\text { Human scale, inside } \\
\text { and outside, } \\
\text { symbolic vision and } \\
\text { etc. }\end{array}$ \\
\hline
\end{tabular}

Fermi characteristics include shape features of traditional architecture which have been used as structural or decorative basis in architecture of Iran. Most experts of architecture do not agree this style of contemporary architecture. In terms of them, form, more than other two categories, is bound to time and place and therefore its sustainability over the architecture of a land, is reduced. From the patterns of Iranian architecture, the different patterns of foursome and cruciform pattern can be noted." The template is actually an abstract inference and because it is more abstract than form, it has more sustainability." [8] But the last group is the most valuable in Iranian architecture; conceptual attributes. The concept, not only in Iranian architecture today, but also in the world architecture, is forever sustainable and repeatable. These features have existed in architecture of Iran before and after the advent of Islam, independent of a particular model or form and coordinated the architecture with human psychological and physiological needs very well. Also today these characteristics can match the new life's body with Iranian Islamic identity with the help of contemporary technology. Some of these concepts can be applied to the following categories:

\subsection{Symbolic Insights}

This feature arouses the searcher sense of human and 
encourages him to move in space and find hidden meanings in architecture." Feeling spiritual greatness in simplicity and purity in Iranian buildings' formation and composition has been considered. This is The strange story of the mysterious Iranian architecture that works with the simplest of materials in regular ground and Its mystery and ambiguity to the followed function impels humans to think again" [6]

\subsection{Human Scales}

One of the long-standing principles of Iranian architecture is compatibility with proportions of human body. In reference [9] Poorjafar quoted from Ardalan that "This architecture is based on the human scale and golden geometric proportions of the human body."

\subsection{Inside and Outside}

The relationship between the outside and the inside is precise. In the culture of this type of architecture, the real value is given to the essence and the inside core and The shell surface is just a virtual cover that protects a reality. This property is deeply rooted in social and philosophical foundations and principles of Iran. The difference between interior and exterior space is the major attribute of Iranian architectural space and is consistent with the culture, customs, worldview and the special lifestyle of Iranians.

\subsection{Diversity but Uniformity}

Despite the very complex appearance of structures and Persian motifs, architecture, sometimes have emerged based on very simple principles. [11] each component of Iranian architecture is complete by itself and also these components together make up one full whole. These components, like very regular cells, present a very complex composition in the form of a collection. However, completeness of the component and the whole, without creating restriction to the whole, is an important characteristic of Iranian architecture.

\subsection{Geometry}

Iranian architecture is linked to the secrets of the creation by geometry. Architecture in its receiving section (human perception and feeling of architecture) requires preparation which is provided by geometry, through the placement of small and large proportion from specified center and place. [6]

\subsection{Transparency and Fluidity (Continuation)}

Amidst the body of the Iranian architecture, space will never be marked decisively. In such a space, the human path or his look, consistently continues; so that, the spatial openings in horizontal and vertical lines, cause the transparency amidst walls and columns

\subsection{Definition and Composition of the Space}

In Iranian architecture, spaces are perfectly defined and properly combined together. Iranian architecture is narrator. Part of this feature, results from legibility of Iran architecture and the semantic and cultural part, expresses the performance and purpose of building, properly. [12]

\subsection{Motion from Substance into Spirit Through Reducing Mass and Increasing Space}

Iranian architecture has always tried to reach the spiritual quality from physical quality by increasing the space and reducing the mass. "Thinning the wall is not the Solution of increasing the space. The light shining through the windows of below the Sheikh Lotfollah mosque's dome, In fact, reduces mass of the dome in terms of human perception." [8]

Table 4. The conceptual attributes of Iranian Islamic architecture.

\begin{tabular}{l|l}
\hline $\begin{array}{l}\text { The conceptual attributes } \\
\text { of Iranian Islamic } \\
\text { architecture }\end{array}$ & Features \\
\hline Symbolic Insights & $\begin{array}{l}\text { Encourage people to move in space and find } \\
\text { the hidden meanings of architecture by } \\
\text { arousing the searcher sense of human } \\
\text { The compatibility of building proportions } \\
\text { with the human organs }\end{array}$ \\
\hline $\begin{array}{l}\text { The exact relationship between the outside } \\
\text { and inside in architecture }\end{array}$ \\
\hline $\begin{array}{l}\text { Inside and outside } \\
\text { Completeness of the component without the } \\
\text { constraints for the whole }\end{array}$ \\
$\begin{array}{l}\text { Geometry } \\
\text { Transparency and fluidity } \\
\text { (continuation) }\end{array}$ & $\begin{array}{l}\text { Architecture connection with the secrets of the } \\
\text { Creation }\end{array}$ \\
\hline $\begin{array}{l}\text { Definition and composition space } \\
\text { Motion from substance into } \\
\text { spirit }\end{array}$ & $\begin{array}{l}\text { Continuous continuity in human path or look. } \\
\text { the continuity of the space }\end{array}$ \\
\hline
\end{tabular}

\section{Discussion and Conclusions}

Iranian-Islamic identity has always reflected very well in Iranian traditional architecture throughout history and with its continuation and also different changes over time, it has maintained its Iranian-Islamic reality. But today, with the changes that the progress of science and technology has created in human life, Iranian architecture has failed to coordinate its historical continuity with developments of the day and caught the identity crisis. Many contemporary architects, for superficial maintaining of this route, have created a new identity of Iranian architecture with copying the form of the traditional architecture of Iran which is different by its nature. While the studies resulting from this research indicates that the attention to Iranian-Islamic architecture does not mean repeating the apparent shape of the traditional architecture of Iran. The architectural shape of every era belongs to the same era people. The thing that maintains identity and reflects the spirit of the time in Iranian architecture is the durable values of Iran architecture. Therefore, Taking inspiration from sustainable patterns of Iranian architecture and modern expression of them by using creativity and skill, is the best way for reflecting the identity in contemporary architecture of this land.

So it seems today's architectural solution depends on a comprehensive understanding of Iranian-Islamic identity. 
With the help of consistent concepts in architectural history of Iran, a solution for suitable organizing of the physical identity and architectural profile can be presented; which reflects the identity and spirit of the time in contemporary architecture. In fact achieving a kind of cultural-social sustainability in architecture of Iran frees it from place and time and can continue the way of traditional architecture of Iran.

\section{References}

[1] Pakzad, J. "Identity \& This Same with Space", Journal of Soffeh. (21 \& 22). 1995, pp. 100-106.

[2] Qotbi, A.A. "The concept of identity and Iranian architecture today". Journal of Ayene Khial. (10). 2008, pp. 78-83.

[3] Sadeghi Pey, N. "A hesitation on the traditional architecture". Journal of Soffeh. (48). 2009, pp. 7-16.

[4] Shayan, H. "The criteria defining the identity of Iranian contemporary architecture: the creation of a theoretical framework for structuring the votes of Iranian contemporary thinkers in case of identity". Journal of Abadi. (70). 201, pp. 102-113.

[5] Hojjat, M. "A conversation with Dr. Hojjat on Iranian-Islamic architecture concept", Journal of Abadi. (70). 2011, pp. 136-141.
[6] Diba, D. "Inspiration and interpretation of the basic concepts of Iranian architecture". Journal of Architecture and Culture. (1). 1999, pp. 100-105.

[7] Soltan Zade, H. "How to reflect the tradition signs in contemporary architecture". Journal of Architecture and Culture. (25). 2006.

[8] Mirmiran, H. "What was the lesson of the past architecture?" Journal of Abadi. (23). 1995, pp. 29-36.

[9] Poor Jafar, M., R.Akbarian, M. Ansari, H.A.Poormand "intellectual approach to the continuity of Iran architecture", Journal of Soffeh. (45). 2007, pp. 90-105.

[10] Schulz, Ch. "The philosophy of the architectural space". Translated by: A. Seyed Sadr, Biabani publication. Tehran, 1998.

[11] Afshar Naderi, K. "Syntagmatic of opposites in Iranian architecture". Journal of Abadi. (19). 1995, pp. 68-75.

[12] Daneshdoost, Y. "Iranian architecture in utterance of four generations of expert architects". Journal of Abadi. (19). 1995, pp. 4-45.

[13] Alexander, Ch. "Architecture and immortality secret". Translated by: Mehrdad Ghayumi Bid Hendi. Shahid Beheshti University publication. Tehran, 2002. 